by Sandeep Singh

\title{
Himalayan Magmatism through space and time
}

\author{
Department of Earth Sciences, Indian Institute of Technology Roorkee, Roorkee-247 667 (India); E-mail:sandpfes@iitr.ernet.in
}

(Received : 25/10/2018; Revised accepted : 20/05/2019)

https://doi.org/10.18814/epiiugs/2020/020022

Available ages from Himalayan domain indicate that Himalaya has experienced different episodes of magmatism starting from Paleoproterozoic, Neoproterozoic, Cambro-Ordovician, Permian through Cenozoic. The Indian and Eurasian Plates together document the Cretaceous and Cenozoic events after collision. The identified age peaks can be correlated with amalgamation and breakup of supercontinent cycles starting from Columbia/Nuna (Paleoproterozoic), Rodinia (Neoproterozoic), Gondwanian (CambroOrdovician), Pangaea (Permian) and Himalayan (Cretaceous to Tertiary). The Himalayan orogenesis incorporates subduction related magmatism followed by collisional magmatism until present time at or near syntaxial bends within the Himalayan domains. It is also very evident that spatially all granitic rocks have southernmost limit at sensu stricto Main Central Thrust (MCT). Paleoproterozoic magmatic rocks are exposed within window zone as well as basal parts of the Higher Himalayan Crystallines (HHC) just above the MCT, however, the Neoproterozoic bodies are restricted very close to the MCT. Cambro-Ordovician bodies are most widespread, whereas, the Permian magmatism is restricted to either to NW or NE Himalaya. But the Himalayan magmatism is present both in Indian as well as Eurasian Plates.

\section{Introduction}

The Himalayas is defined as a $2500-\mathrm{km}$ long arc bounded by two structural syntaxes: Nanga Parbat (8125 m) on the west and Namcha Barwa (7782 m) on the east (Fig. 1a), and has resulted from continentcontinent collision no later than 57 Ma (Leech et al., 2005, 2007). Prior to collision, Indian Plate and Eurasian Plate converged upto $3600 \pm 35 \mathrm{~km}$ (van Hinsbergen et al., 2012), which included the oceanic plate as well as continental crust (Greater India). Postcollisional tectonics accommodated crustal shortening ranging from $3000 \mathrm{~km}$ to 318 or $419 \mathrm{~km}$ (for summary see Singh et al., 2009), and recently this has been estimated to the order of $2675 \pm 699 \mathrm{~km}$ (van
Hinsbergen et al., 2012) along various tectonic boundaries viz. the South Tibetan Detachment System (STDS), the Main Central Thrust (MCT), the Main Boundary Thrust (MBT), the Himalayan Frontal Fault (HFF) and their splays (Jain et al., 2002; Steck, 2003; Yin, 2006 and references therein).

Attempts have been made to reconstruct the position of Indian Plate with respect to various plate tectonic configurations. PreHimalayan configuration of the Himalaya (Greater India) in view of Paleoproterozoic Columbia/Nuna Supercontinent along with Mesoto Neoproterozoic Rodinia Supercontinent has not been taken into consideration for the position of Greater India in details (Dalziel, 1991, 1992; Powell et al., 1993; Li et al, 1996; Dalziel et al., 2000; Rogers and Santosh, 2002, 2009; Meert, 2014). There has been formation of a supercontinent which got episodically amalgamated and broken up in Earth's history causing the supercontinental cycles (Nance and Murphy, 2013 and references therein), peaks of U-Pb crystallization ages, magmatic rock formation match with amalgamation and breakup of these supercontinents (Voice et al., 2011).

Since the proposal of one supercontinent Pangaea during Late Paleozoic (Wegner, 1912), various supercratons have been stabilized during the Mesoarchean till Paleoproterozoic, which included Vaalbara (between 3,400-2,800 Ma), Superia (between 2,800-2,400 Ma) and Sclavia (between 2,600-2,200 Ma) (Bleeker, 2003). Each of these supercontinent cycles requires collision leading to amalgamation and rifting, which leads to breakup, and has been documented in geological past with episodic peaks of collisional orogenesis and rift-related mafic dyke swarms (Worsley et. al, 1984). Based on the episodic peaks of U$\mathrm{Pb}$ ages first true supercontinent accretion happened to be Columbia/ Nuna (between 1.9 and 1.5 Ga with a 1.8 Ga orogeny), followed by Rodinia (ca. 1,000-750 Ma), Gondwana/Pannotia (ca. 550-180 Ma) and Pangaea (ca. 250-180 Ma) (Rogers, 1996; Rogers and Santosh, 2002, 2009; Zhao et al., 2002, 2004). The accretion of these supercontinents have also been correlated with increased geothermal gradient caused due to rising mantle plume leading to heat transfer in the continental lithosphere (Kuzmin et al., 2010; Taylor et al., 2010) and enhancement of production of continental crust (Taylor and McLennan, 1995; Condie, 1998, 2014; Wang et al., 2009) by fractional crystallization and extraction of felsic magma from mafic residues (Jaupart et al., 2016) and causing crustal preservation peaks as shown by igneous and detrital zircon populations (Condie, 2014).

The reporting of magmatic ages from the Himalayan region has been attempted by earlier workers mostly in the light of geographical or litho-tectonics of Himalaya. This paper is an attempt to review the magmatic ages with respect to supercontinental cycles within the Himalayan domain. 


\section{Magmatic ages}

The Himalayan domain within the Indian and the Eurasian Plates exposes various magmatic events ranging from Proterozoic to Late Cenozoic, mainly based on field relationships, nature of xenoliths, degree of metamorphism, petrographic similarities, structural trends, etc. by earlier workers (McMahon, 1884; Greisbach, 1893; Auden, 1935; Wadia, 1928, 1957; and others), prior to the application of isotopic methods of age determination (Fig. 1b; Singh, 2001, 2005 and references therein). Initially, the ages reported were by $\mathrm{Rb}-\mathrm{Sr}$ and Sm-Nd whole-rock dating techniques (Singh, 2001: Singh and Jain, 2003 and references therein). In the recent past, the use of U-Pb systematics has shown an increase due to its advantages over other techniques (Singh, 2005). There has also been advancement from conventional time-consuming ID-TIMS (isotopic dilution thermal ionization mass spectrometry) data acquisition technique to rapid in situ U-Pb analysis (by SIMS or LA-MC-ICP-MS). These rapid analytical techniques have generated large amounts of data set. This has also diverted the focus from age of crystallization to sediment finger printing by detrital zircon studies. In this paper emphasis is only on crystallization ages of magmatic bodies from the Himalaya.

The first data published from Himalaya was by K-Ar technique in Nepal Himalaya (Krummenacher, 1961). However, the first Rb-Sr age was reported by Jager etal. (1971) on Mandi granite of Himachal Pradesh (Singh, 2001 and references therein). The first high resolution $\mathrm{U}-\mathrm{Pb}$ dating in Himalaya was reported on zircons from Ladakh Batholith by Honegger et al. (1982), followed by dating of zircon

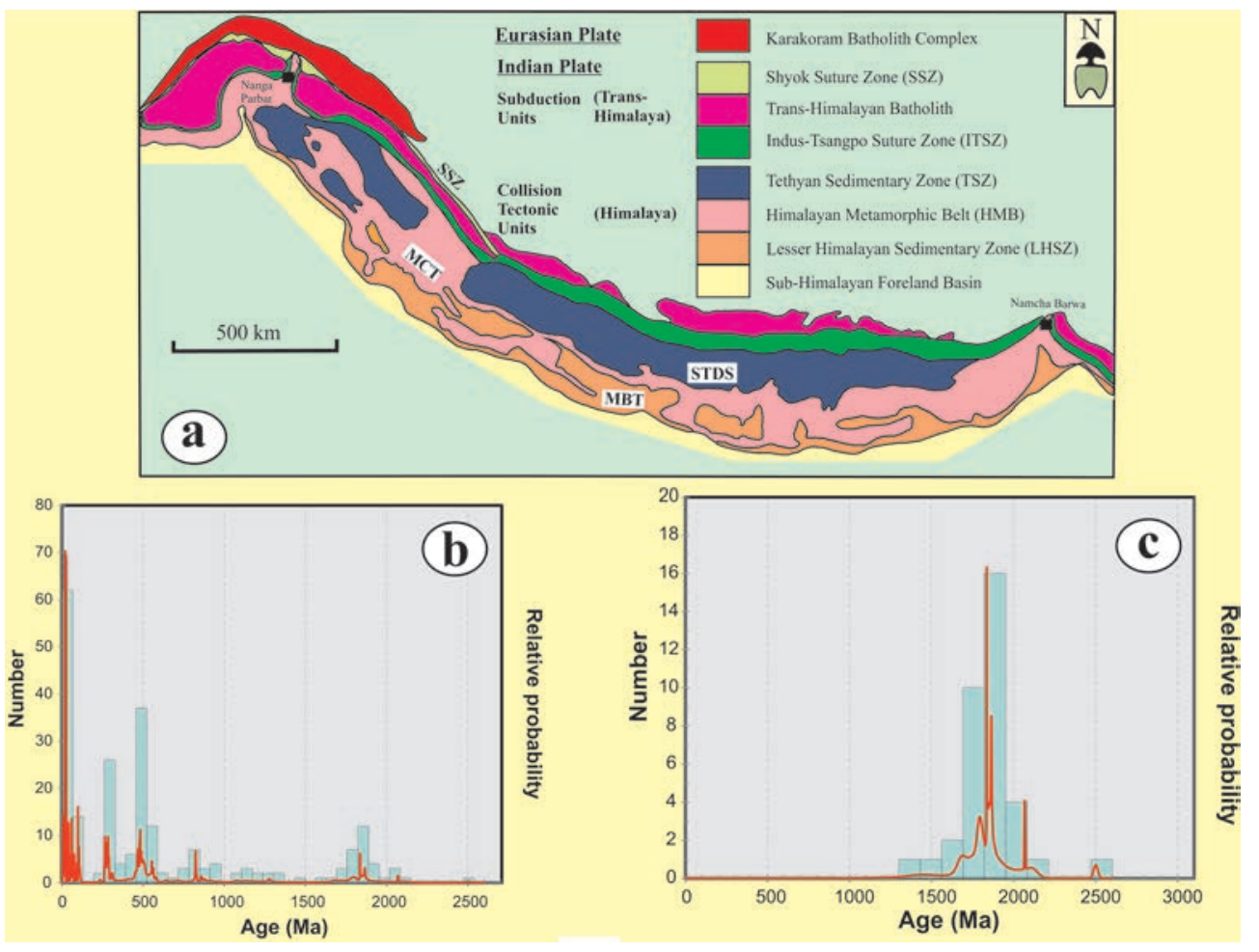

Figure 1. (a) Simplified regional geological map of Himalayas with components of Indian Plate and Eurasian Plate. MBT - Main Boundary Thrust; MCT - Main Central Thrust; STDS - South Tibetan Detachment System (Modified after Singh and Jain, 2003; Singh, 2019). (b) Histogram and relative probability curve of the published data set on Himalayan magmatic bodies (Singh, 2001, 2005; Singh et al., 2009; Dhiman and Singh, 2018, 2020; Shellnutt, 2018 and references therein). (c) Histogram and relative probability curve of the published data set on Paleoproterozoic magmatic bodies lying above MCT and below Vaikrita Thrust. and monazite from the Palung Granite of Nepal Himalaya (Schärer and Allegre, 1983). Furthermore, it was followed by Makalu Granite of Nepal Himalaya and Gangadese Pluton of Trans-Himalayan region in Tibet, respectively (Schärer, 1984; Schärer et al., 1984). These ages were obtained by the conventional Thermal Ionization Mass Spectrometry. However, the first date using Secondary Ion Mass Spectrometry (SIMS) was obtained by Zeitler et al. (1989) on NangaParbat Harmosh Massif in Pakistan by SHRIMP (Sensitive High Resolution Ion Micro Probe) analysis. In Indian Himalaya, the first SHRIMP analysis was published by Singh et al. (2002) on Chor Granite followed by many others (Singh, 2005 and references therein).

Various studies within the Himalayan domain indicate mafic magmatism during Neoarchean-Proterozoic ( $2.5 \mathrm{Ga})$ within the inner Lesser Himalayan (iLH) Sequence as well as sporadic $2.0 \mathrm{Ga}$ granitoids, widespread Paleoproterozoic (1.8 Ga) (Fig. 1c), Neoproterozoic (0.9-0.8 Ga; Fig. 2b) and Cambro-Ordovician (0.46 Ga; Fig. 2c) voluminous granitoid (Fig. 2; Singh, 2001, 2005; Singh and Jain 2003 and references therein). In addition, there was widespread Lower Permian mafic volcanism, which could be related to the opening of Neo-Tethyan Ocean across the Himalaya in Pangaea Supercontinent 300-250 Ma ((Figs. 3a, b;Wegner, 1912; Smith and Livermore, 1991; Murphy and Nance, 2008; Stampfli et al., 2013; Zhao et al., 2018). These volcanics are popularly known as Panjal Trap, Phe Volcanics etc. in NW Himalaya and Abor Volcanics in Eastern Himalaya (Singh et al., 2019). There are occurrences of a few granitoids of the same age, mostly in NW Himalaya (Figs. 3a, b; also Shellnutt, 2018), viz. Maklad granite (Zeitler, 1988), LoeSar Granite, Lower Swat (Anczkiewcz et al., 1998) Parkachic and Sanko in Zanskar (Nobel et al., 2001), Biotite granite below Shishma-Pangma Leucogranite (Searle et al., 1997), and Yunam Granite in Upper Lahaul (Spring et al., 1993) within NW Himalaya (also see Singh, 2005 and references therein). This magmatism is correlated with extensional tectonic setting (Spring et al., 1993; Nobel et al., 2001; Chauvet et al., 2008). The Permian magmatic bodies are occurring as dykes or small plutons within the THS or close to it (Fig. 3; also see Singh, 2005 and references therein and Singh et al., 2019). This magmatic phase is followed by the Himalayan subduction-related island arc magmatism due to separation of Indian Plate from Gondwanaland and its movement towards north at different rates (Klootwijik et al., 1985). In Dras and surrounding areas, an island arc during Cretaceous time was followed by widespread calcalkaline I-type magmatism, which developed the Karakoram Axial and Trans-Himalayan Batholiths; this activity continued into Tertiary Leucogranite across the Greater Indian domain as well as Eurasian 
Plate (Figs. 4a, b). The Trans-Himalayan Batholith represents Cretaceous to Early Tertiary Andean-type magmatic arc with calcalkaline characters (Kumar, 2005). The age constrains on these bodies range from 113 to 46 Ma (Schärer et al., 1984; Singh, 2001, 2005; Singh et al., 2007, and references therein), whereas, the collisionrelated magmatism is mainly tourmaline-bearing leucogranite (TBL), a S-Type granite.

These various ages can be correlated with amalgamation and breakup of the supercontinental cycles like Columbia (Paleoproterozoic), Rodinia (Neoproterozoic), Gondwanian (Cambro-Ordovician), Pangaea (Permian) and lastly can be put in the bracket of Himalayan orogenesis (Cretaceous and Tertiary). The following section reviews plausible tectonic scenario within Himalayan domain in view of various age peaks (Fig. 1b).

\section{Paleoproterozoic Scenario}

Globally three basic models have been proposed for positioning India (not Greater India) in Columbia Supercontinent configuration with very limited paleomagnetic data (Kohn et al., 2010). Rogers and Santosh (2002) and Zhao et al. (2004) tried to position India away from North America with India having passive margin, whereas Hou et al. (2008) placed India directly adjacent to North America with subduction zone in the north. The Paleoproterozoic magmatism within Greater India domain are either rift-related (Bhat, 1984, 1987; Bhat and Ahmad, 1985) or possess within plate characters (Singh, et al., 2009; Larson et al., 2017; Martin, 2017); these strongly support passive margin of India, as stated by Rogers and Santosh (2002) and Zhao et al. (2004).

Numerous ages, determined from volcanics and granites in various parts of Lesser Himalayan para-autochthon exposed in many windows and metamorphic allochthon in the NW-Himalaya, distinctly cluster around 2.5 Ga and 1.8-2.0 Ga (Fig. 1b), and reveal their extensive involvement in the Cenozoic Himalayan Collision zone. Extensive orthoquartzite-volcanic association in the Lesser Himalayan paraautochthon window zone of Kistwar, Kulu-Rampur and iLH sedimentary belt of Garhwal-Kumaon Himalaya plays an important role in tracing the Proterozoic evolutionary trend within the Himalayan domain (Fuchs, 1975; Sharma, 1977; Valdiya, 1980; Bhat and Le Fort, 1992). The Proterozoic interstratified mafic-volcanic bodies with orthoquartzite-limestone indicate a typical platform setup. Geochemically, these interstratified volcanic are typically characterized by transitional tholeitic-to-alkalic composition with relatively enriched incompatible trace elements, similar to basalt erupted in a so-called "plume” setting (Bhat, 1984, 1987; Bhat and

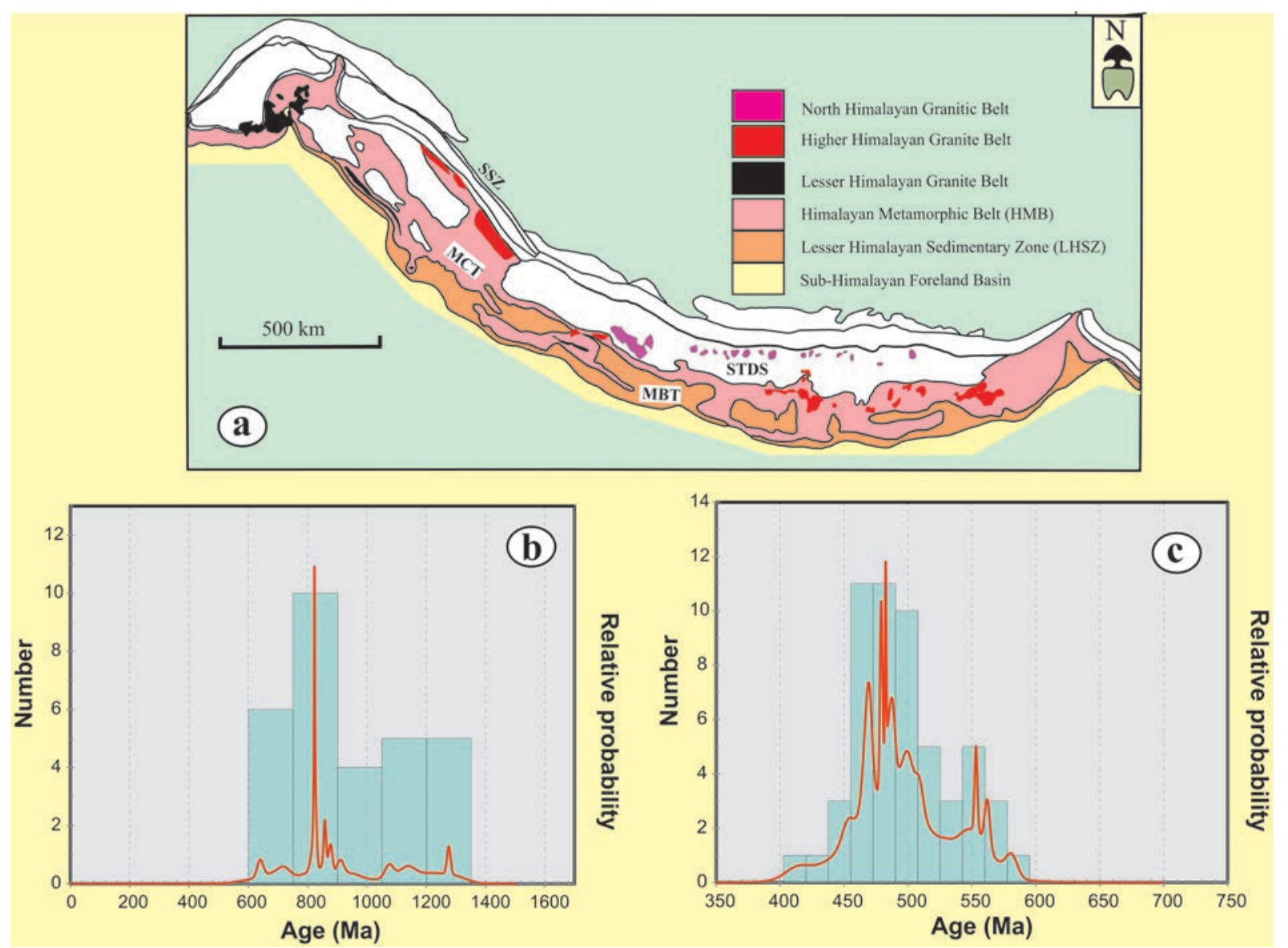

Figure 2. (a) Simplified regional geological map of Himalayas with Higher Himalayan Granite Belt, which also host Himalayan Leucogranites and North Himalayan Granite Belt (modified after Singh and Jain, 2003). Tethyan sedimentary sequences are shown as white unfilled zone to show distribution of various magmatic bodies.(b) Histogram and relative probability curve of the published data set on Neoproterozoic magmatic bodies (Singh et al., 2002; DiPietro and Pogue, 2004; Richards et al., 2006; Yin et al., 2010; Web et al., 2011; Mottram et al., 2014; Clarke et al., 2016; Dhiman and Singh, 2018, 2020). (c) Histogram and relative probability curve of the published data set on Cambro-Ordovician magmatic bodies along with other Pan-African magmatism. 
Ahmad, 1985). Bhat and Le Fort (1992) have obtained a Sm-Nd whole-rock isochron from these volcanic of the Kulu-Rampur Window representing intense rift-related volcanism of $2509 \pm 94 \mathrm{Ma}$, thus constraining the rift basin around Archean-Proterozoic boundary. Some of these orthoquartzite-volcanic platform sequences are intruded by $1.8 \mathrm{Ga}$ granitoids of which the Kishtwar and Bandal bodies reveal $\mathrm{Rb}-\mathrm{Sr}$ whole rock isochron of $1861 \pm 32$ and $1840 \pm 70 \mathrm{Ma}$, respectively (Frank et al., 1977; Miller and Frank, 1992), whereas U$\mathrm{Pb}$ zircon SHRIMP age of Bandal is 1866 $\pm 4 \mathrm{Ma}$ (Singh et al., 2009).

In addition, geochronological data are now available from many metamorphic allochthonous of the HHC and the Lesser Himalaya and reveal almost coeval ages of this extremely important phase of plutonism (Fig. 1b). Of these, two U-Pb zircon primary crystallization ages of granitoids from the HHC in immediate vicinity of the KuluRampur Window are most significant and indicate 1.8-2.0 Ga (Singh et al., 2006, 2009) anorogenic within plate granitoids (WPG) like the Kaghan valley granitoids in Pakistan (Spencer, 1992) or younger Champawat granitoids in Uttarakhand Himalaya (Singh, et al., 1993). Looking at the data, three major magmatic phases can be demarcated; (i) the 2.5 Ga Rampur Volcanics (Sm-Nd WR age; Bhat and Le Fort, 1992), (ii) the 2.0 Ga grey granitoids from basal part of the HHC (U-Pb isotopic dilution zircon age; Singh, 1993; Singh et al., 2006) and (iii) the $1.8 \mathrm{Ga}$ Wangtu granitoids and Kulu-Bajura nappe rock (NirathBaragaon mylonite gneiss or Garh Formation of Sharma, 1977) also from HHC (U-Pb isotopic dilution zircon ages and SHRIMP ages; Singh, 1993; Singh et al, 2009).

The oldest magmatic phase appears to be basic volcanics, interstratified with orthoquartzitelimestone association of KuluRampur and Kishtwar Window zone, and are affected by the $1.8 \mathrm{Ga}$ Bandal-Kishtwar granitoids (Singh, 1993; Miller et al., 2001; Singh et al., 2009). However, in the HHC the 1.8 to $2.0 \mathrm{Ga}$ granitoids represent the earliest magmatic phase intruding the still older fine-grained pelitic and banded biotite gneiss. As no deformation episodes are associated with this anorogenic magmatic event, it appears that the biotite gneiss and thinly banded pelitic sequence of the HHC represent original geoclinal facies of shale and thin sandstone intercalations, probably coeval with the 2.5 Ga orthoquartzite-volcanic platform association of foreland, deposited on an older unknown basement. This setting appears to be similar to the basinal setting of the
Aravalli, Dharwar and other Proterozoic basins of Peninsular India (Ahmad et al., 2008; Manikyamba and Kerrich, 2012; Kale, 2016; references therein). Therefore, one can visualize an Early Proterozoic extensive ensialic basin in the Himalayan region with its shoulder, located southward in the Lesser Himalaya, represented by $2.5 \mathrm{Ga}$ sedimentation of volcanic-orthoquartzite platform association and geoclinal pelites of the Higher Himalaya. Mafic volcanism was more likely to be associated with adiabatic rise of mantle plume in an extremely attenuated lithosphere rather than ocean floor spreading due to horizontal movement of continental plate by convection roll (Bhat, 1987). Geochemical signatures of the 1.8-2.0 Ga granitoids from the Kulu-Rampur and Kishtwar Window and the HHC reveal anorogenic WPG emplacement and possibly represent rise of the Early Proterozoic mantle plume diapirs within extended crust, both in the Lesser and Higher Himalayan domains. Heat source from such plumes has possibly partially melted lower and middle continental crust to generate granitoids, which is also evident from the high ${ }^{87} \mathrm{Sr} /{ }^{86} \mathrm{Sr}$ initial
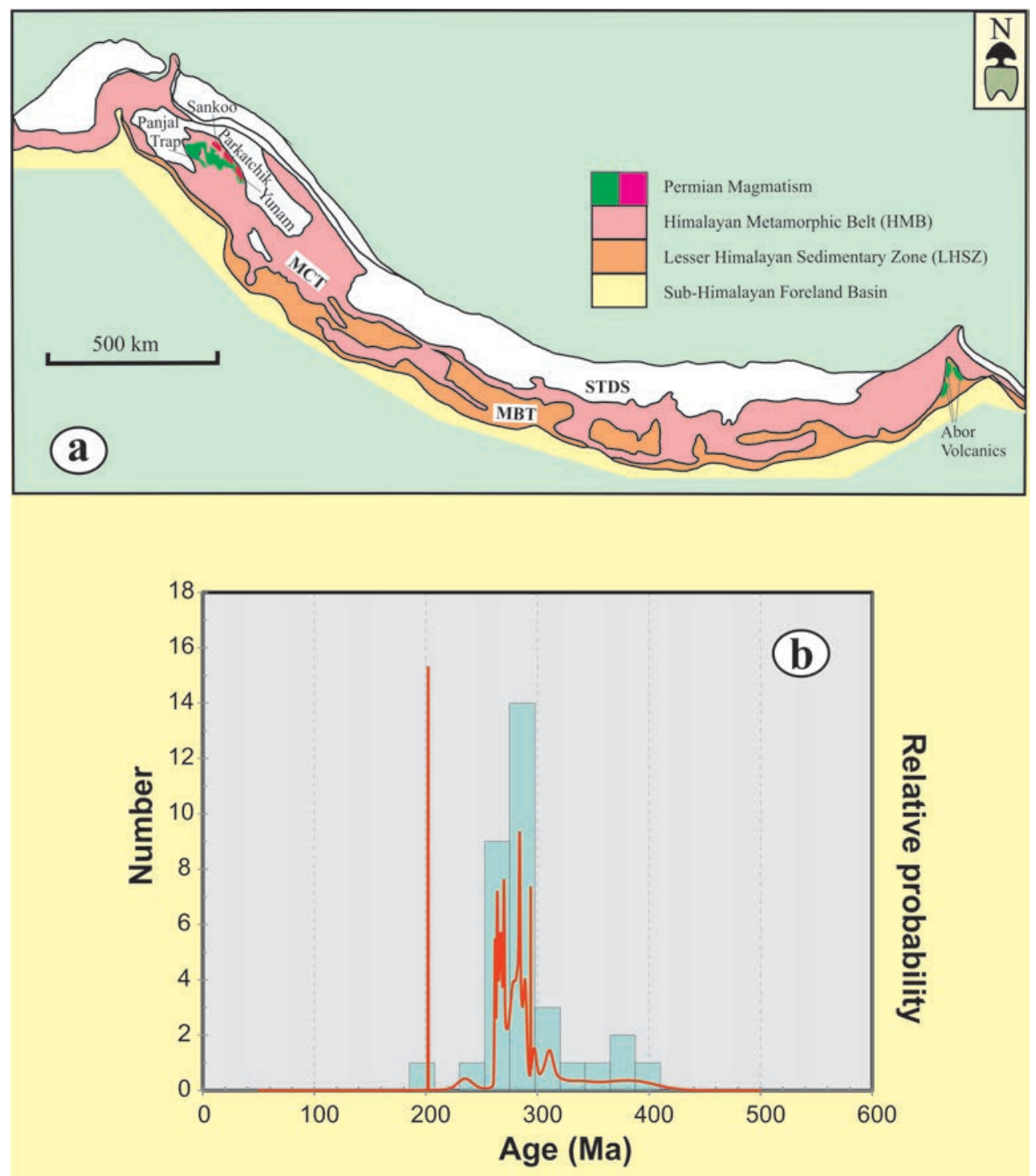

Figure 3.(a) Simplified regional geological map of Himalayas with Permian magmatism. Tethyan sedimentary sequences are shown as white unfilled zone to show distribution of various magmatic bodies.(b) Histogram and relative probability curve of the published data set on Permian magmatism (table 1 of Shellnutt, 2018 and references therein). 

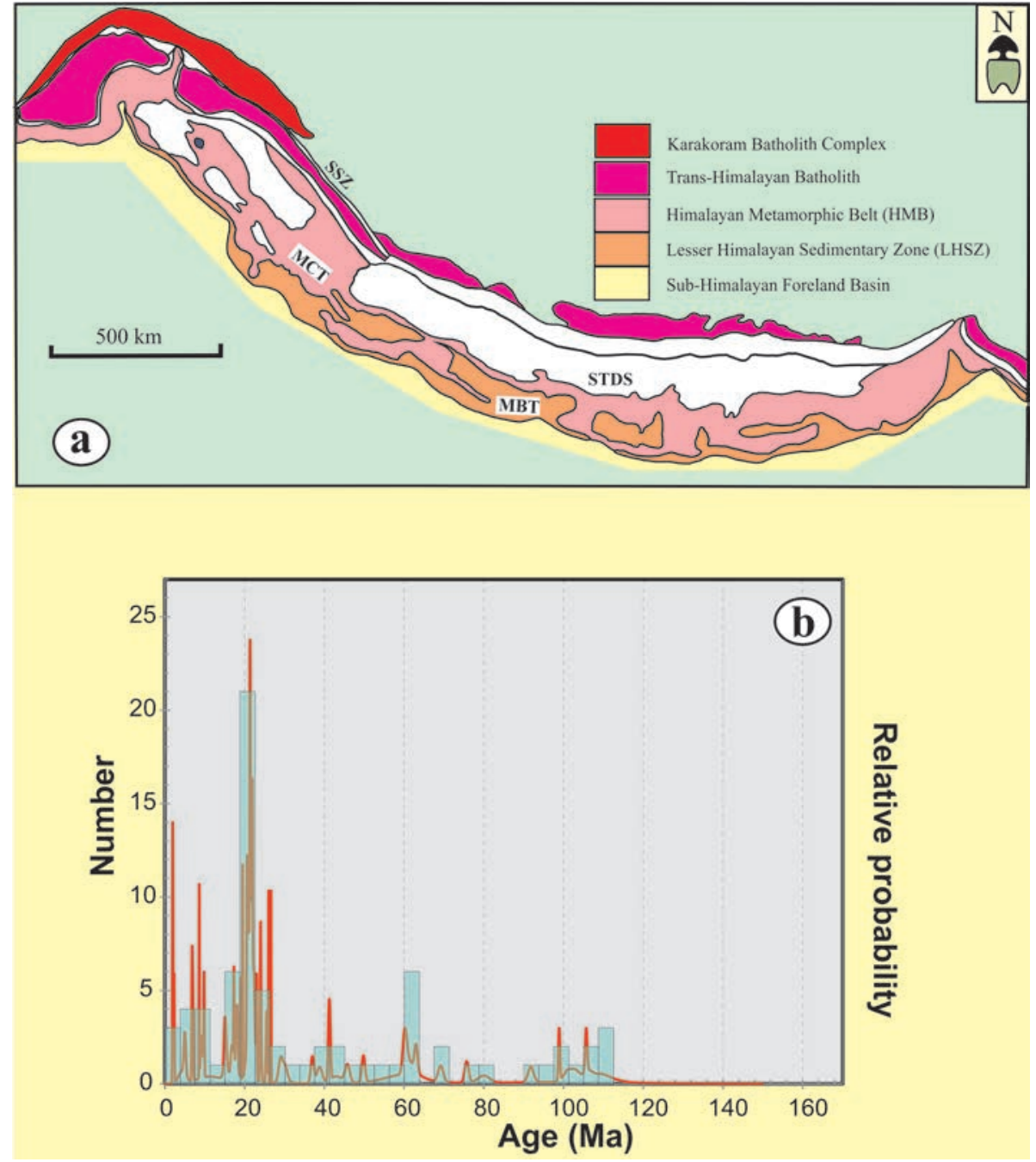

Figure 4. (a) Simplified regional geological map of Himalayas with Trans-Himalayan Batholith and Karakoram Batholithic Complex (modified after Singh and Jain, 2003). Tethyan sedimentary sequences are shown as white unfilled zone.(b)Histogram and relative probability curve of the published data set on Cretaceous and Tertiary magmatic bodies.

ratio between 0.70 and 0.74 from these bodies. This find support from the rise of small granitoids plutons like Bandal, Kishtwar and Wangtu, which incorporated numerous deformed metamorphosed restites and xenoliths, as well.

\section{Neoproterozoic Scenario}

Peaks of U-Pb crystallization ages of indicate magmatic events between $1000 \mathrm{Ma}$ and 720 Ma that mark the assembly and breakup of Rodinia supercontinents, and characterized by intracontinental mobile belt formation along with widespread shearing, and posttectonic magmatism (Unrug, 1997). The name Rodinia Supercontinent was proposed by McMenamin and McMenamin (1990). Recent work revealed that this supercontinent had amalgamated during MesoNeoproterozoic time, whereas classical geodynamic scenario indicates 800-700 Ma span isrelated to the Rodinia breakup (Merdith et al., 2017; Oriolo et al., 2017; references therein). After assembly, the Rodinia underwent rifting at ca 800-700 Ma during the Late Mesoproterozoic, and lead to opening of a major rift between Laurentia and Eastern Gondwana cratons. The amalgamation of Gondwanaland has been recorded after 550 Ma (Merdith et al., 2017; Oriolo et al., 2017), causing a supercontinent cycle which has started at 630 Ma and continued upto 550-530 Ma (Dalziel, 1997; Meert and Torsvik, 2003; Collins and Pisarersky, 2005; Cawood and Buchan, 2007). Bleeker (2003) and Ernst and Bleeker (2010) compiled timing of supercontinent formation and have shown reasonable synchronicity with U-Pb zircon peaks. However, Bradley (2011) and Condie (2011) correlated the data with assembly of Rodinia, between 1200 and $900 \mathrm{Ma}$, and assembly of Gondwana around 600 Ma.

During breakup of Rodinia or amalgamation of Gondwanaland magmatic rocks have played an important role in Greater India (Himalayan) domain. There are very limited Neoproterozoic magmatic ages reported from Himalayan Domains (Fig. 2b). Geochemical characteristics of these magmatic activities within plate granite field suggest a continuation of a passive northern margin of India even during Neoproterozoic time (Singh et al., 2002). The Chor, Chaupal, Audi, all in Himachal (Singh et al., 2002; Webb et al., 2011), orthogneiss in Sikkim (Mottram et al., 2014), Tashi Yangtse augen gneiss and Kuru Chu augen gneiss in Bhutan (Thimm et al., 1999; Richards et al., 2006), Zimithang augen gneiss in Kameng and Subansiri augen gneiss in Arunachal (Yin et al., 2010; Clarke et al., 2016) along with other bodies and recently-recognized Dalhousie and Dhauladhar granite (Dhiman and Singh, 2018, 2020) represent Neoproterozoic magmatic events within the Himalayan domain. These granites are representing a major site of juvenile crustal addition by thermal perturbation during fragmentation/breakup of Rodinia.

\section{Cambro-Ordovician Scenario}

The Cambro-Ordovician magmatism is marked by emplacement of series of granite plutons within the HHC south of Main Central Thrust (MCT) as the Lesser Himalayan Granitic Belt or close to South Tibetan Detachment System (STDS) as two-mica granites. These bodies are also exposed within a series of domes as a discontinuous culminations within the Tethyan Sedimentary sequence north of the STDS as independent plutons like the Kaghan, Lhago-Kangri, Kangmar, Nyimaling, Tso-Morari, Rupsu, Jispa, Kade, Kokhsar, Kaghan to name a few (Gansser, 1977; Frank et al., 1977; Wang et al., 1981; Spencer, 1993; Girard and Bushy, 1999). These bodies are mostly occurring as gneissic bodies.

During the Gondwana amalgamation, southern tip of India collided with Congo and northwest margin with Azania and northern Madagascar during early Pan African event. On the other hand, Australia-East Antarctica collided with India during late Pan-African event (Le Fort et al., 1983, 1986); also known as Kuunga orogeny 
(Merdith et al., 2017). A low-pressure contact metamorphism along with pre-Himalayan fabric (around Mandi area) has also been associated with these Cambro Ordovician granites (Baud et al., 1982; Guntli, 1993; Purkayastha et al., 1999; Girard and Bussy, 1999; Singh and Jain, 2008). Along with this pronounced thermal event coeval garnet ages are also been reported from the various localities (Chor mountain: $485 \pm 19$ Ma, $473 \pm 14$ Ma - Bhargava et al., 2016; Alaknanda valley: 534 $\pm 24 \mathrm{Ma}$ - Argles et al., 1999; NW Himalaya:

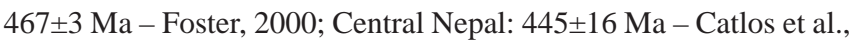
2000; Namche migmatites: 548 \pm 17 Ma - Catlos et al., 2002; Barun Gneiss: 436 \pm 8 Ma - Catlos et al., 2002), recording Pan-African Caledonian - Hercynian orogenic cycles within the Himalayan domain, making this an important event. In the Nepal Himalaya, Gehrels et al (2003) observed that the Cambro-Ordovician granites are cutting across the regional ductile folds and foliation (Stocklin and Bhattarai, 1977) and post-date regional garnet-grade metamorphism (Stocklin, 1980). Based on these observations they proposed a Late Cambrian - Middle Ordovician period of thin-skinned thrusting in the Himalaya. Looking at intrusion of rocks along the earliest Himalayan fabric, contact metamorphism and garnet ages the Pan-African period indicates a major tectonic event within the Himalayan domain, corresponding to the Kurgiakh Orogeny by Srikantia (1977) and Kuunga Orogeny by Merdith et al., (2017).

\section{Himalayan Orogenic Scenario}

The Himalayan orogenesis involved about $1200 \pm 200 \mathrm{~km}$ northward movement since the Indian Plate separated from Antarctica. Initially there was subduction of the Neo-Tethyan oceanic plate during Cretaceous followed by Cenozoic collision (Jain et al., 2002 and references therein). As a result of the northward subduction, Dras volcanic arc has formed with ages ranging from 105 to $65 \mathrm{Ma}$ (Sharma et al., 1978; Honegger et al., 1982; Schärer etal., 1984; Reuber, 1989; Reuber et al., 1989). At the same time, the Kohistan arc also developed with calc-alkaline batholith emplacement between 120-85 Ma (for review see Singh, 2001, 2005 and references therein) and development of Trans-Himalayan Batholith representing Andean-Type magmatism due to melting of north dipping Tethyan oceanic crust (Schäreret al., 1984). Both the batholiths have developed below an island arc situated along the southern margin of Eurasia (Raz and Honegger, 1989). The age of Trans-Himalayan bodies predate collision and represent subduction-related magmatism ranging from 102-54 Ma (for details see Singh, 2001, 2005, Singh and Jain, 2003 and references there in)

The subduction-related phase was followed by collision-related magmatism of smaller volumes forming discontinuous small pluton known as the Higher Himalayan Leucogranites (HHL). These intrude closer to the STDS. These syn-to post-Himalayan leucogranites have attained large attention due to its collision-related characters (Le Fort, 1986; Le Fort et al., 1987; Zeitler et al., 1993; Searle, 1996; Harrison et al., 1997; Searle et al., 1999; Schneider et al., 1999, 2001, Singh, 2001, 2005, 2019 and references therein), and are interpreted to have resulted from either (i) crustal anatectic melting due to fluid migration during intracontinental thrusting along the MCT (Le Fort et al., 1987; France-Lanordand Le Fort, 1988), (ii) decompression-controlled dehydration melting due to slip along the STDS, which controls the emplacement of leucogranite plutons (Searle at al., 1992; Guillot and Le Fort, 1995), or (iii) vapor-absent muscovite dehydration melting of metamorphic rocks due to shear heating along continuous active decollement (Harrison et al., 1997, 1999). However, irrespective of the mechanism of its generation, leucogranite belt was emplaced $~ 24$ Ma after collision (Davidson et al., 1997; Searle et al., 1997, 1999; Guillot et al., 1999; Montomoli et al., 2017). U-Th-Pb ages of these HHL range between 24 Ma to 12 Ma (Searle and Godin, 2003; Carosi et al., 2013 and references therein) and frequently occupy peaks of higher Himalaya. Crystallization ages from the HHL indicate younger ages as compared to peak metamorphic ages, e.g. 44-26 Ma of Garhwal Himalaya (Prince et al., 2000, 2001; Foster et al., 2000), 41-22 Ma of Himachal Himalaya (Stübneret al., 2014), 37 - 28 Ма in Zanskar Himalaya (Vance and Harris, 1999; Walker et al., 1999), $36 \mathrm{Ma}$ (Hodges et al., 1996) and 36-28 Ma (Laccarino et al., 2015) of Annapurna in Nepal, and 36-34 Ma in Bhutan (Edward and Harrison, 1997). The $\varepsilon_{\mathrm{Nd}}$ values of some of the plutons range between -11 to 18 indicating that there are no mantle components (Vigneress and Burg, 2003 and references therein) rather they match well with the $\varepsilon_{\mathrm{Nd}}$ values (-13 to -19) of the Vaikrita Group of rocks (Ahmad et al., 2000).

Apart from these, a few coeval in situ melts have also been reported from the migmatite zone (e.g., Harris et al., 2004; Rubatto et al., 2013, Singh, 2019). In the NW Himalaya, the migmatite zone is present in the center of HHC with highest grade of metamorphism, and show flowage and in situ melt generation of tourmaline bearing leucogranite (Singh, 2019). These tourmalines are the result of high boron content (Hu et al., 2018 and references therein). The zircon growth within the in situ melt from migmatites along Bhagirathi Valley reveals episodic influx between $46 \mathrm{Ma}$ and $20 \mathrm{Ma}$ (Singh, 2019) indicating a coeval event related with peak metamorphism and HHL emplacement.

\section{Conclusions}

The magmatic ages reported from Himalayan domain are biased towards preservation of part of any supercontinental cycle as they reflect only addition of continental crust, whereas, any supercontinental cycle involve both breakup and amalgamation. The magmatic ages from Himalayan domain represent apparent episodic distribution of ages involving various tectonic processes such as plume, rifting, subduction, slab break-off, collision etc. This can also be correlated with supercontinent cycles and continental growth and has also been reflected in the global-data of peaks of U-Pb ages and their relations with continental growth. The first true supercontinent is that of Columbia/Nuna with the next to be Rodinia supercontinent followed by Gondwana and Pangaea. These supercontinent cycles involve complete separation prior to re-amalgamation into single supercontinents.

The Paleoproterozoic ages from Himalayan domain are overlapping well with Columbia/Nuna Supercontinent cycle and are occurring within the Inner Lesser Himalayan Sequence as well as the basal part of the Higher Himalayan Crystallines (HHC), close to sensu stricto Main Central Thrust (MCT), as described by Heim and Gansser (1939). However, limited Neoproterozoic data from granitoids are available from NW Himalaya as well as Eastern Himalaya and can be correlated with Rodinia Supercontinent cycle. The CambroOrdovician magmatism is not restricted to a zone rather they are distributed within HHC (baring basal part), Tethyan Sedimentary Sequences (TSS) and northern domal structures (e.g. Tso-Morari, Kangmar etc.) due to its widespread nature indicating a wider zone. This event of Cambro-Ordovician magmatism can be correlated with Gondwana Supercontinent cycle. Permian ages are also reported 
mainly from NW Himalaya as well as Eastern Himalaya and related with formation of Pangaea. The Indian Plate and the Eurasian Plate collision involve subduction-related magmatism followed by collisionrelated magmatism. The continental collisional event also indicates recycling of pre-existing crust as well as formation of juvenile crust.

\section{Acknowledgements}

Author thanks Department of Science and Technology, New Delhi and Ministry of Earth Sciences for funding at various stages of the study which helped in understanding the Himlayas. During the course my guru A K Jain, along with David G Gee, Stefan Claesson, Rm Manickavasagam, PG Andreasson, Ake Johnsson, Rasoul Sorkhabhi, Mary Leech, Neal McNaughton helped in understanding the intricacies. There has always been constant encouragement from late K.R. Gupta which is thankfully acknowledged. I also thank all my students of $\mathrm{PhD}$ and postgraduate dissertation who made me think beyond the realm of actual work, to name a few are Rajeev Kumar, Th Nikunja Bihari Singha, Rimpi Dhiman.

\section{References}

Crossley, D., Hinderer, J., and Boy, J.P., 2004, Regional gravity variations in Europe from superconducting gravimeters. Journal of Geodynamics, v. 38, pp. 325-334.

Ahmad, T., Harris, N., Bickle, M., Chapman, H., Bunbury, J., and Prince, C., 2000, Isotopic constraints on the structural relationships between the Lesser Himalayan Series and the High Himalayan Crystalline Series, Garhwal Himalaya. Geological Society of American Bulletin, v. 112, pp. 467-477.

Ahmad, T., Deb, M., Tarney, J., and Raza, M., 2008, Proterozoic Mafic Volcanism in the Aravalli-Delhi Orogen, Northwestern India: Geochemistry and Tectonic Framework. Journal of Geological Society of India, v. 72, pp. 93-111.

Anczkiewicz, R., Burg, J.P., Hussain, S.S., Dawood, H., Ghazanfar, M. and Chaudhry, M.N., 1998, Stratigraphy and structure of the Indus Suture in the lower Swat, Pakistan, NW Himalaya. Journal of Asian Earth Sciences, v. 16(2-3), pp.225-238. doi.org/10.1016/ S0743-9547(98)00003-8.

Argles, T.W., Prince, C.I., Foster, G.L., Vance, D., 1999. New garnets for old? Cautionary tales from young mountain belts. Earth and PlanetaryScienceLettersv. 172,pp.301-309.

Auden, J.B., 1935. Traverses in the Himalaya. Records of Geological survey of India, v. 69,pp.123-167.

Baud, A., Arn, R., Bugnon, P., Crisinel, A., Dolivo, E., Escher, A., Hammerschlag, J., Marthaler, M., Masson, H., Steck, A. and Tieche, J., 1982, The Gondwana-Peri-Gondwana relationships in the Eastern Zanskar area of Ladakh (Himalaya in India). Bulletin De La SocieteGeologique De France, v. 24(2), pp.341-361.

Bhargava, O.N., Thoni, M., and Miller, 2016, Isotopic evidence of Early Paleozoic metamorphism in the Lesser Himalaya (Jutogh Group), Himachal Pradesh India: its implication. Himalayan Geology, v. 37 (2), pp. 73-84.

Bhat, M.I., 1984, The Evolution of the Southern Passive Margin of the Himalayan Tethys: Model Implications and Constraints I. Journal of Petroleum Geology,v. 7(3), pp.341-349.doi.org/ 10.1111/j.1747-5457.1984.tb00185.x

Bhat, M.I., 1987, Spasmodic rift reactivation and its role in the preorogenic evolution of the Himalayan region.Tectonophysics,v. 134(1-3), pp.103-127. doi.org/10.1016/0040-1951(87) 90252-6

Bhat, M. I., and Ahmad, T., 1985, Petrogenesis of the Abor Volcanics,
Eastern Himalaya, Abstract International Volcanology Congress, New Zealand.

Bhat, M.I. and Le Fort, P., 1992,Sm-Nd age and petrogenesis of Rampur metavolcanic rocks, NW Himalayas: Late Archaean relics in the Himalayan belt. Precambrian Research, v. 56(3-4), pp.191210. doi.org/10.1016/0301-9268(92)90101-S

Bleeker, W., 2003, The late Archean record: a puzzle in ca. 35 pieces. Lithos, v.71(2-4), pp.99-134. doi.org/10.1016/j.lithos. 2003.07.003

Bradley, D.C., 2011, Secular trends in the geologic record and the supercontinent cycle.Earth-Science Reviews,v. 108(1-2), pp.1633. doi.org/10.1016/j.earscirev.2011.05.003

Carosi, R., Montomoli, C., Rubatto, D. and Viscona, D., 2013, Leucogranite intruding the South Tibetan detachment in western Nepal: implication for exhumation models in the Himalayas. Terra Nova, v. 25, pp. 478-489.

Catlos, E.J., Sorensen, S.S., Harrison, T.M., 2000, Th-Pb ionmicroprobe dating of allanite. American Mineralogists, v. 85, pp. 633-648.

Catlos, E. J., Harrison, T. M., Manning, C. E., Grove, M., Rai, S. M., Hubbard, M. S., Upreti, B. N., 2002, Records of the evolution of the Himalayan orogen from in situ Th-Pb ion microprobe dating of monazite: Eastern Nepal and western Garhwal. Journal of Asian Earth Sciences, v. 20, pp. 459-479.

Cawood, P.A., and Buchan, C., 2007, Linking accretionary orogenesis with supercontinent assembly.Earth-Science Reviews,v. 82(3-4), pp.217-256. doi.org/10.1016/j.earscirev.2007. 03.003

Chauvet, F., Lapierre, H., Bosch, D., Guillot, S., Mascle, G., Vannay, J.C., Cotten, J., Brunet, P. and Keller, F., 2008, Geochemistry of the Panjal Traps basalts (NW Himalaya): records of the Pangaea Permian break-up.Bulletin de la Société géologique de France,v. 179(4), pp.383-395. doi.org/10.2113/gssgfbull.179.4.383

Clarke, G.L., Bhowmik, S.K., Ireland, T.R., Aitchison, J.C., Chapman, S.L. and Kent, L., 2016,Oligo-Miocene Monazite Ages in the Lesser Himalaya Sequence, Arunachal Pradesh, India; Geological Content of Age Variations. InAGU Fall Meeting Abstracts.

Collins, A.S., and Pisarevsky, S.A., 2005, Amalgamating eastern Gondwana: the evolution of the Circum-Indian Orogens.EarthScience Reviews,v. 71(3-4), pp.229-270. doi.org/10.1016/j. earscirev. 2005.02.004

Condie, K.C., 1998, Origin and evolution of earth: principles of historical geology. Pearson College Division.

Condie, K.C., 2011, The supercontinent cycle (Chapter 8). In: Earth as an Evolving Planetary System,Academic Press, New York, pp. 317-355

Condie, K.C., 2014, Growth of continental crust: a balance between preservation and recycling. Mineralogical Magazine,v. 78(3), pp.623-638. doi.org/10.1180/minmag.2014.078.3. 11

Dalziel, I.W., 1991, Pacific margins of Laurentia and East AntarcticaAustralia as a conjugate rift pair: Evidence and implications for an Eocambrian supercontinent.Geology,v. 19(6), pp.598601.doi.org/10.1130/0091-7613(1991)019<0598: PMOLAE $>2.3 . \mathrm{CO} ; 2$

Dalziel, I., 1992, On the organization of American plates in the Neoproterozoic and breakout of Laurentia. GSA Today,v. 2, pp.237-241.

Dalziel, I.W., 1997, Overview: Neoproterozoic-Paleozoic geography and tectonics: Review, hypothesis, environmental speculation. Geological Society of America Bulletin,v. 109(1), pp.1642.doi.org/10.1130/0016-7606(1997)109<0016: ONPGAT>2.3.CO;2

Dalziel, I.W., Lawver, L.A., and Murphy, J.B., 2000, Plumes, orogenesis, and supercontinental fragmentation.Earth and Planetary Science Letters,v. 178(1-2), pp.1-11. doi.org/10.1016/ S0012-821X(00)00061-3.

Davidson C., Grujic D.E., Hollister L.S., Schmid S.M., 1997, 
Metamorphic reactions related to decompression and synkinematic intrusion of leucogranite, High Himalayan Crystallines, Bhutan. Journal of Metamorphic Geology, v. 15, pp.593-612.

Dhiman R, and Singh S, 2018, Remelting of Neoproterozoic Dalhousie and Dhauladhar granite during Cambro-Ordovician: Constraints from in situ U-Pb zircon geochronology, Himachal Pradesh, NW Himalaya. 33rd Himalaya Karakorum Tibet Workshop, 10-12 September 2018, Lausanne, Switzerland. DOI: 10.5281/zenodo.1403887

Dhiman, R. and Singh, S. 2020, Neoproterozoic and CambroOrdovician magmatism: Episodic growth and reworking of continental crust, Himachal Himalaya, India. International Geology Review. Doi: 10.1080/00206814.2020.1716399

Edward M.A., and Harrison T.M., 1997, When did the roof collapse? Late Miocene north-south extension in the high Himalaya revealed by $\mathrm{Th}-\mathrm{Pb}$ monazite dating of the Khula Kangri granite. Geology, v. 25, pp. 543-546.

Ernst, R., and Bleeker, W., 2010, Large igneous provinces (LIPs), giant dyke swarms, and mantle plumes: significance for breakup events within Canada and adjacent regions from 2.5 Ga to the Present. Canadian Journal of Earth Sciences,v. 47(5), pp. 695739.doi.org/10.1139/E10-025.

Foster, G.L., 2000, The pre-Neogene thermal history of the Nanga Parbat Haramosh Massif and the NW Himalaya. PhD dissertation, The Open University, United Kingdom, 345 pp.

Foster G., Kinny P., Prince C., Vance D., and Harris N., 2000, The significance of monazite $\mathrm{U}-\mathrm{Th}-\mathrm{Pb}$ age data in metamorphic assemblages; a combined study of monazite and garnet chronometry. Earth and Planetary Science Letters, v. 181, pp. 327-340.

France-Lanord C., Lefort P., 1988. Crustal melting and granite genesis during the Himalayan collision orogenesis. Transaction of Royal Society of Edinburg, v. 99, pp. 183-195.

Frank,W., Thoni, M., andPurtscheller,F., 1977, Geology and petrography of Kullu-South Lahul area.Colloquesinternationaux du C.N.R.S., v. 286, pp. 147-172.

Fuchs, G., 1975, Contributions to the geology of the North-Western Himalayas.Geolog. Bundesanst.v. 32.

Gehrels, G.E., DeCelles, P.G., Martin, A., Ojha, T.P., Pinhassi, G. and Upreti, B.N., 2003, Initiation of the Himalayan orogen as an early Paleozoic thin-skinned thrust belt.GSA Today,v. 13(9), pp.4-9.

Gansser, A., 1977, The great suture zone between Himalaya and Tibeta preliminary account. Colloquium International Centre of Natural Research Sciences, v. 33, pp. 181-192.

Girard, M. and Bussy, F., 1999, Late Pan-African magmatism in the Himalaya: new geochronological and geochemical data from the Ordovician Tso Morari metagranites (Ladakh, NW India). Schweizerischemineralogische und petrographische Mitteilungen, v. 79, pp.399-418. doi10.5169/ seals - 60215

Griesbach, C.L., 1893, On the geology of the country between Chapper Rift and Harnai in Baluchistan.Records Geological Survey of India,v. 26(4), pp.113-147.

Guillot S., and Le Fort P., 1995, Geochemical constraints on the bimodal origin of High Himalayan leucogranites. Lithos, v.35,pp.221-234.

Gulliot, S., Cosca, M., Allemand, P.,Le Fort, P., 1999, Contrasting metamorphic and geochronologic evolution along the Himalayan belt. In: Macfarlane, A., Sorkhabi, R. B. Quade, J. (Eds.) Himalaya and Tibet: Mountain Roots to Mountain Tops. Geological Society of America Special Papers, 328, pp. 117-128.

Guntli, P., 1993, Geologie und Tektonik des Higher und Lesser Himalaya imGebiet von Kishtwar, SE Kashmir (NW Indien)(Doctoral dissertation, ETH Zurich).

Harris, N.B.W., Caddick, M., Kosler, J., Goswami, S., Vance, D., and Tindle, A.G., 2004, The pressure-temperature-time path of migmatites from the Sikkim Himalaya Journal of Metamorphic Geology,v. 22,pp. 249-264

Harrison, T.M., Lovera, O.M., and Groove, M., 1997, New insights into the origin of two contrasting Himalayan granite belts. Geology, v. 25,pp. 899-902.

Harrison T.M., Grove M., Lovera O.M., Catlos E.J., D’andrea J., 1999, The origin of Himalayan anatexis and inverted metamorphism: Models and constraints. Journal of Asian Earth Sciences, v. 17, pp.755-772.

Heim, A., and Gansser, A., 1939, Central Himalaya. Hindustan Publishing; Delhi.

Hodges K.V., Parrish R.R.,and Searle M.P., 1996, Tectonic evolution of the central Annapurna Range, Nepalese Himalaya. Tectonics, v. 15, pp. 1264-1291.

Honegger, K., Dietrich, V., Frank, W., Gansser, A., Thöni, M., and Trommsdorff, V., 1982, Magmatism and metamorphism in the Ladakh Himalayas (the Indus-Tsangpo suture zone).Earth and Planetary Science Letters,v. 60(2), pp.253-292. doi.org/10.1016/ 0012-821X(82)90007-3

Hou, G., Santosh, M., Qian, X., Lister, G.S. and Li, J., 2008, Configuration of the Late Paleoproterozoic supercontinent Columbia: insights from radiating mafic dyke swarms.Gondwana Research,v. 14(3), pp.395-409. doi.org/10.1016/j.gr.2008.01.010

Hu, G., Zeng, L., Gao, Li-E, Liu, Q., Chen, H. and Guo, Y., 2018, Diverse magma sources for the Himalayan leucogranites: Evidence from B-Sr-Nd isotopes. Lithos, v. 314-315, pp. 88-99

Jager, E., Bhandari, A.K. and Bhanot, V.B., 1971, Rb-Sr age determinations on biotites and whole rock samples from the Mandi and Chor granites, Himachal Pradesh, India. Ecolog. Geol. Helv., v. 64(3), pp. 521-527.

Jain, A.K., Singh, S. and Manickavasagam, R.M., 2002, Himalayan collision tectonics. Gondwana Research Group.

Jaupart, C., Mareschal, J.C. and Iarotsky, L., 2016, Radiogenic heat production in the continental crust.Lithos,v. 262, pp.398-427. doi.org/10.1016/j.lithos.2016.07.017

Kale, V.S. 2016, Proterozoic Basins of Peninsular India: Status within the GlobalProterozoic Systems. Proceedings Indian National Science Academy, v. 82 (3), pp. 461-477. DOI: 10.16943/ptinsa/ 2016/48461

Klootwijk, C.T., Conaghan, P.J. and Powell, C.M., 1985, The Himalayan Arc: large-scale continental subduction, oroclinal bending and back-arc spreading.Earth and Planetary Science Letters,v. 75(2-3), pp.167-183. doi.org/10.1016/0012821X(85)90099-8

Kohn, M.J., Paul, S.K. and Corrie, S.L., 2010, The lower Lesser Himalayan sequence: A Paleoproterozoic arc on the northern margin of the Indian plate. Geological Society of America Bulletin,v. 122(3-4), pp.323-335.doi.org/10.1130/ B26587.1

Krummenacher, D., 1961,Determinationed' age isotopiquefaites sur quelquesrouches de L' Himalayan Du Nepal Par La Methode KAr. Bulletin Suisse Min. Pet., v, 41, pp. 273-283.

Kumar, R., 2005, Tectonics, Geochemistry and Geochronology of the Ladakh Batholith, Trans-Himalaya. Unpublished Ph.D. Thesis, IITroorkee.

Kuzmin, M.I., Yarmolyuk, V.V. and Kravchinsky, V.A., 2010, Phanerozoic hot spot traces and paleogeographic reconstructions of the Siberian continent based on interaction with the African large low shear velocity province.Earth-Science Reviews, v. 102(1-2), pp.29-59. doi.org/10.1016/j.earscirev. 2010.06.004

Laccarino,S., Montomoli,C.,Carosi, R.,Massonne,H.J., Langone, A., Visonà,D., 2015, Pressure-temperature-time-deformation path of kyanite-bearing migmatitic paragneiss in the Kali Gandaki valley (Central Nepal): Investigation of Late Eocene-Early Oligocene melting processes. Lithos, v.231, p.103-121. 
Larson, K., Piercey, S. and Cottle, J., 2017, Preservation of a Paleoproterozoic rifted margin in the Himalaya: Insight from the Ulleri-Phaplu-Melung orthogneiss.Geoscience Frontiers. doi.org/ 10.1016/j.gsf.2017.05.010.

LeFort, P., 1986, Metamorphism and magmatism during the Himalayan collision.Geological Society, London, Special Publications,19(1), pp.159-172.doi.org/10.1144/GSL.SP.1986 .019.01.08

LeFort, P., Michard, A., Sonet, J. and Zimmermann, J.L., 1983, Petrography, geochemistry and geochronology of some samples from the Karakorum Axial Batholith (northern Pakistan).Granites of Himalayas, Karakorum and Hindu Kush. Institute of Geology, Punjab University, Lahore, pp.377-387.

Le Fort, P., Debon, F., Pecher, A., Sonet, J. and Vidal, P. 1986 The 500 Ma magmatic event in Alpine southern Asia, a thermal episode at Gondwana Scale. Sci. de la Terre Mem., v. 47, pp. 191209.

Le Fort, P., Cuney, M., Deniel, C., Lanords, C.F., Sheppard, N.F., Upreti, B.N., and Vidal, P., 1987, Crustal generation of the Himalayan leucogranite. Tectonophysics,v. 134, pp. 39-57.

Leech, M.L., Singh, S., Jain, A.K., Klemperer, S.L., and Manickavasagam, R.M., 2005, The onset of India-Asia continental collision: early, steep subduction required by the timing of UHP metamorphism in the western Himalaya.Earth and Planetary Science Letters,v. 234(1-2), pp.83-97. doi.org/10.2747/ 0020-6814.49.4.313

Leech, M.L., Singh, S., and Jain, A.K., 2007, Continuous metamorphic zircon growth and interpretation of U-Pb SHRIMP dating: An example from the Western Himalaya.International Geology Review,v. 49(4), pp.313-328. doi.org/10.2747/00206814.49.4.313

Li, Z.X., Zhang, L., and Powell, C.M., 1996, Positions of the East Asian cratons in the Neoproterozoic supercontinent Rodinia.Australian Journal of Earth Sciences,v. 43(6), pp.593604.doi.org/10.1080/08120099608728281.

Manikyamba, C., and Kerrich, R. 2012, Eastern Dharwar Craton, India: Continental lithosphere growth by accretion of diverse plume and arc terranes. Geoscience Frontiers, v. 3 (3), pp. 225240.https://doi.org/10.1016/j.gsf.2011.11.009.

Martin, A.J., 2017, A review of definitions of the Himalayan Main Central Thrust.International Journal of Earth Sciences,v. 106(6), pp.2131-2145.doi 10.1007/s00531-016-1419-8

McMahon, C.A., 1884, Microscopic structures of some Himalayan granites and gneissose granites.Records Geological Survey of India,v. 17, pp.53-73.

McMenamin, M.A., and McMenamin, D.L.S., 1990, The emergence of animals: the Cambrian breakthrough. Columbia University Press.

Meert, J.G., 2014, Strange attractors, spiritual interlopers and lonely wanderers: the search for pre-Pangaean supercontinents. Geoscience Frontiers,v. 5(2), pp.155-166. doi.org/10.1016/j.gsf. 2013.12.001

Meert, J.G., and Torsvik, T.H., 2003, The making and unmaking of a supercontinent: Rodinia revisited.Tectonophysics,v. 375(1-4), pp.261-288. doi.org/10.1016/S0040-1951(03)00342-1

Merdith, A.S., Collins, A.S., Williams, S.E., Pisarevsky, S., Foden, J.D., Archibald, D.B., Blades, M.L., Alessio, B.L., Armistead, S., Plavsa, D., and Clark, C., 2017, A full-plate global reconstruction of the Neoproterozoic.Gondwana Research,v. 50, pp.84-134. doi.org/10.1016/j.gr.2017.04.001

Miller, C., and Frank, W., 1992, Geochemistry and isotope geology of Proterozoic and early Paleozoic granitoids in the NW Himalayas: Oxford University, 7th Himalaya-Karakoram-Tibet Workshop

Miller, C., Thöni, M., Frank, W., Grasemann, B., Klötzli, U., Guntli, P., andDraganits, E., 2001, The early Palaeozoic magmatic event in the Northwest Himalaya, India: source, tectonic setting and age of emplacement.Geological Magazine,v. 138(3), pp. 237-251 doi.org/10.1017/ S0016756801005283

Montomoli, C., Carosi, R., Rubatto, D., Viscona, D., and Laccasino, S., 2017, Tectonic activity along the inner margin of the South Tibetan Detachment constrained by syntectonic leucogranite emplacement in western Bhutan. Italian Journal of Geoscience, v. 136 (1), pp. 5-14.

Mottram, C.M., Warren, C.J., Regis, D., Roberts, N.M., Harris, N.B., Argles, T.W., and Parrish, R.R., 2014, Developing an inverted Barrovian sequence; insights from monazite petrochronology. Earth and Planetary Science Letters,v. 403, pp.418-431. doi.org/ 10.1016/j.epsl.2014.07.006

Murphy, J.B., and Nance, R.D., 2008, The Pangaea conundrum. Geology,v. 36, pp. 703-706.

Nance, R.D., and Murphy, J.B., 2013, Origins of the supercontinent cycle.Geoscience Frontiers,v. 4(4), pp.439-448. doi.org/10.1016/ j.gsf.2012.12.007.

Noble, S.R., Searle, M.P., and Walker, C.B., 2001, Age and tectonic significance of Permian granites in Western Zanskar, High Himalaya. Journal of Geology, v. 109, pp. 127-135.

Oriolo, S., Oyhantçabal, P., Wemmer, K. and Siegesmund, S., 2017, Contemporaneous assembly of Western Gondwana and final Rodinia break-up: Implications for the supercontinent cycle.Geoscience Frontiers,v. 8(6), pp.1431-1445. doi.org/ 10.1016/j.gsf.2017.01.009

Powell, C.M., Li, Z.X., McElhinny, M.W., Meert, J.G., and Park, J.K., 1993, Paleomagnetic constraints on timing of the Neoproterozoic breakup of Rodinia and the Cambrian formation of Gondwana.Geology,v. 21(10),pp.889-892. doi.org/10.1130/ 0091-7613(1993)021<0889: PCOTOT>2.3.CO;2

Prince, C.I., Kosler, J., Vance, D., and Gunther, D., 2000, Comparison of Laser ablation ICP-MS and isotope dilution REE analyses implications for Sm-Nd garnet geochronology. Chemical Geology, v. 168, pp. 255-274.

Prince C. I., Harris N., and Vance D., 2001, Fluid-enhanced melting during prograde metamorphism. Journal of Geological Society of London, v. 158, pp. 233-241.

Purkayastha, S., Verma, P.K., Jain, A.K., Manickvasagam, R.M., and Ghosh, T.K., 1999, Growth and rotation of porphyroblasts and development of shear/extensional foliation in Baggi-MandiPandoh region, Western Himalaya-implications on the Himalayan tectonics. Gondwana Research Group Memoir,v. 6, pp.3-37.

Raz, U., and Honegger, K., 1989, Magmatic and tectonic evolution of the Ladakh block from field studies. Tectonophysics, v. 161, pp. 107-118.

Reuber, I., 1989, The Dras Arc: two successive volcanic events on eroded oceanic crust. Tectonophysics, v. 161, pp. 93-106.

Reuber I, Montigny R, Thuizat R., and Heitz, A., 1989, K-Ar ages of ophiolites and arc volcanics of the Indus suture zone: clues on the early evolution of the Neo-Tethys; Eclog. Geol. Helv.,v. 82, pp. 699-715

Richards, A., Parrish, R., Harris, N., Argles, T., and Zhang, L., 2006, Correlation of lithotectonic units across the eastern Himalaya, Bhutan.Geology,v. 34(5), pp.341-344. doi.org/10.1130/G22169.1

Rogers, J.J., 1996, A history of continents in the past three billion years.The Journal of Geology,v. 104(1), pp.91-107.

Rogers, J.J., and Santosh, M., 2002, Configuration of Columbia, a Mesoproterozoic supercontinent.Gondwana Research,v. 5(1), pp.5-22. doi.org/10.1016/S1342-937X(05)70883-2.

Rogers, J.J., and Santosh, M., 2009, Tectonics and surface effects of the supercontinent Columbia.Gondwana Research,v. 15(3-4), pp.373-380. doi.org/10.1016/j.gr.2008.06.008.

Rubatto, D., Chakraborty, S., and Dasgupta, S., 2013, Timescales of 
crustal melting in the Higher Himalayan Crystallines (Sikkim, Eastern Himalaya) inferred from trace element-constrained monazite and zircon chronology. Contribution to Mineralogy and Petrology, v. 165, pp. 349-372.

Schärer, U., 1984, The effect of initial 230Th disequilibrium on young $\mathrm{U}-\mathrm{Pb}$ young ages: the Makalu case, Himalaya. Earth and Planetary Science Letters, v. 67, pp. 191-204

Schärer, U. and Allègre, C.J., 1983, The Palung granite (Himalaya); high-resolution UPb systematics in zircon and monazite.Earth and Planetary Science Letters,v. 63(3), pp.423-432. doi.org/ 10.1016/ 00 12-821X(83)90115-2

Schärer, U., Xu, R.H., and Allègre, C.J., 1984, U-Pb geochronology of Gangdese (Transhimalaya) plutonism in the Lhasa-Xigaze region, Tibet.Earth and Planetary Science Letters,v. 69(2), pp.311320. doi.org/10.1016/0012-821X(84)90190-0

Schneider, D.A., Edwards, M.A., Kidd, W.S.F., Zeitler, P.K., and Coath, C. D., 1999, Early Miocene anatexis identified in the western syntaxis: Southern Nanga Parbat, Pakistan Himalaya. In: Abstr. volume, 14th Himalayan-Karakoram-Tibet workshop, KlosterEttal, Germany, pp. 136-137.

Schneider, D.A., Zeitler, P.K., Kidd, W.S.F., and Edwards, M.A., 2001, Geochronological constraints on the tectonic evolution and exhumation of Nanga Parbat, Western Himalaya Syntaxis, Revisited. Journal of Geology, v. 109,pp. 563-583.

Searle MP. 1996, Cooling history, erosion, exhumation, and kinematics of the Himalaya-Karakoram-Tibet orogenic belt. In:Yin, A., HarrisonT.M. (eds.) The Tectonic Evolution of Asia, pp. 110-37. New York: Cambridge University Press

Searle, M.P., and Godin, L., 2003, The South Tibetan Detachment and the Manaslu Leucogranite: A structural reinterpretation and restoration of the Annapurna-Manaslu Himalaya., Nepal. The Journal of Geology, v. 111, pp. 505-523.

Searle M.P., Waters D.J., Rex D. C., and Wilson R.N., 1992, Pressure, temperature and time constraints on Himalayan metamorphism from eastern Kashmir and western Zanskar. Journal of Geological Society of London, v. 149, pp. 753-773.

Searle, M.P., Parrish, R.R., Hodges, K.V., Hurford, A., Ayres, M.W., and Whitehouse, M.J., 1997, Shisha Pangma leucogranite, south Tibetan Himalaya: Field relations, geochemistry, age, origin, and emplacement.The Journal of Geology,v. 105(3), pp.295318.doi.org/10.1086/ 515924

Searle, M.P., Noble, S.R., Hurford, A.J. and Rex, D.C., 1999, Age of crustal melting, emplacement and exhumation history of the Shivling leucogranite, Garhwal Himalaya. GeologicalMagzine, v. 136 (5), pp. 513-525.

Sharma, V.P., 1977, Geology of Kulu-Rampur belt, Himachal Pradesh.Memoir Geological Societyof India,v. 106, pp.235-407.

Sharma, K.K., Sinha, A.K.,Bagdasarian,G.P., and Gukasian, R.Ch.,1978, Potassium Argon dating of Dras volcanics, Shyok volcanics and Ladakh granite, Ladakh NW Himalaya, Himalayan Geology, v. 8(1), pp. 288 - 295.

Shellnutt, J.G., 2018,ThePanjal Traps. In:Sensarma, S., and Storey, B.C. (eds) Large Igneous Provinces from Gondwana and Adjacent Regions. Geological Society of London, Special Publication v. 463, pp. 59-86. Doi: 10.1144/SP463.4

Singh, A.K., Chung, Sun-Lin, Bikramaditya, R., Lee, H-Y, and Khogenkumar, S., 2019, Zircon U-Pb geochronology, Hf isotopic compositions, and petrographic study of Abor volcanic rocks of Eastern Himalayan Syntaxis, Northeast India: Implications for eruption during breakup of Eastern Gondwana. Geological Journal, DOI: 10.1002/gi.3477.

Singh, B.N., Goel, O.P., Joshi, M., and Sheraton, J.W., 1993, Geochemistry and petrogenesis of Champawat Granitoids occurring around Dhanughat, Distt. Pithoragarh, U.P. Journal of Geological Society of India, v. 42, pp. 289-302.
Singh, S., 1993, Collision Tectonics: Metamorphic and Geochronological constraints from parts of Himachal Pradesh, NW-Himalaya. Unpublished Ph.D. Thesis, Univ. Roorkee, Roorkee, 289 pp.

Singh, S., 2001,Status of geochronological studies in Himalaya: a review. Journal of Indian Geophysical Union, v. 5 (1), pp. 57-72.

Singh, S., 2005, A review of U-Pb ages from Himalayan Collisional Belt. Journal of Himalayan Geology, v. 26 (1), pp. 61-76.

Singh, S., 2019, Protracted zircon growth in migmatites and in situ melt of Higher Himalayan Crystallines: U-Pb ages from Bhagirathi valley, NW Himalaya, India. Geoscience Frontiers, v. 10, pp. 793-809. https://doi.org/10.1016/j.gsf.2017.12.014

Singh, S., and Jain, A. K. 2003, Himalayan granitoids.Journal of the Virtual Explorer,v. 11, pp. 1-20.

Singh, S., and Jain, A.K., 2008, Pan African Mandi Granite in the Lesser Himalaya: its field relationship and SHRIMP U-Pb zircon dating. In: Pan African Event: India and Antarctica. Geological Survey of IndiaSpecial Publication No. 91, pp. 70-78.

Singh, S., Barley, M.E., Brown, S.J., Jain, A.K., and Manickavasagam, R.M., 2002, SHRIMP U-Pb in zircon geochronology of the Chor granitoid: evidence for Neoproterozoic magmatism in the Lesser Himalayan granite belt of NW India.Precambrian Research,v. 118(3-4), pp. 285-292. doi.org/10.1016/S0301-9268(02)001079

Singh, S., Claesson, S., Jain, A.K., Gee, D.G., Andreasson, P.G., and Manickavasagam, R.M., 2006, 2.0 Ga granite of the lower package of the Higher Himalayan Crystallines (HHC), MagladKhad, SutlejValley, Himachal Pradesh, India.Journal of Geological Society of India, v. 67 (3), pp. 295-300.

Singh, S., Kumar, R., Barley, M.E., and Jain, A.K., 2007, SHRIMP $\mathrm{U}-\mathrm{Pb}$ ages and depth of emplacement of Ladakh Batholith, Eastern Ladakh, India.Journal of Asian Earth Sciences,v. 30(34), pp.490-503. doi.org/10.1016/j.jseaes.2006.12.003

Singh, S., Jain, A.K., and Barley, M.E., 2009, SHRIMP U-Pb c. 1860 Ma anorogenic magmatic signatures from the NW Himalaya: implications for Palaeoproterozoic assembly of the Columbia Supercontinent.Geological Society London, Special Publications, v. 323(1), pp.283-300.doi.org/10.1144/SP323.14

Smith, A.G., and Livermore, R.A., 1991, Pangaea in Permian to Jurassic time: Tectonophysics, v. 187, pp. 135-179.

Spencer, D.A., 1992, Geochemistry of the peraluminous Higher Himalayan crystalline granite basement, Upper Kaghan, Pakistan.In: Searle, M.P., and Treloar, P.J. (Eds.), Seventh Himalaya-Karakoram-Tibet Workshop, Programme and Abstracts, Oxford.

Spring, L., Bussy, F., Vannay, J.C., Huon, S., and Cosca, M.A., 1993, Early Permian granitic dykes of alkaline affinity in the Indian High Himalaya of Upper Lahul and SE Zanskar: geochemical characterization and geotectonic implications.Geological Society London, Special Publications, v. 74(1), pp.251-264. doi.org/ 10.1144/GSL.SP.1993.074.01.18.

Srikantia, S.V., 1977, The Sundernagar Group: its geology, correlation and significance as stratigraphically the deepest sediment in the Peninsular or Lesser Himalaya.Journal of the Geological Society of India,v. 18(1), pp.7-22.

Stampfli, G.M., Hochard, C., Vérard, C., Wilhem, C., and Raumer, J.von, 2013, The formation of Pangaea. Tectonophysics,v. 593, pp.1-19

Steck, A., 2003, Geology of the NW Indian Himalaya. Eclogae Geologicae Helvetia, v. 96, pp.147-196.

Stöcklin, J., 1980, Geology of Nepal and its regional frame: Thirtythird William Smith Lecture.Journal of the Geological Society,v. 137(1), pp.1-34. doi.org/10.1144/gsjgs. 137.1.0001

Stöcklin, J., and Bhattarai, K.D., 1977, Geology of the Kathmandu area and central Mahabharat range, Nepal. Nepal Department of 
Mines and Geology, Himalayan Report.

Stübner, K., Grujic, D., Parrish, R.R., Roberts, N.M.W., Kronz, A., Wooden, J., and Ahmad, T., 2014, Monazite geochronology unravels the timing of crustal thickening in NW Himalaya. Lithos, v. 210-211, pp. 111-128

Taylor, S.R., and McLennan, S.M., 1995, The geochemical evolution of the continental crust.Reviews of Geophysics,v. 33(2), pp.241265. doi.org/10.1029/95RG00262.

Taylor, T.R., Giles, M.R., Hathon, L.A., Diggs, T.N., Braunsdorf, N.R., Birbiglia, G.V., Kittridge, M.G., Macaulay, C.I., and Espejo, I.S., 2010, Sandstone diagenesis and reservoir quality prediction: Models, myths, and reality.American Association of Petroleum GeologyBulletin,v. 94(8), pp.1093-1132. DOI:10.1306/ 04211009123

Thimm, K.A., Parrish, R.R., Hollister, L.S., Grujic, D., Klepeis, K., Dorji, T., 1999, New U_/Pb data from the MCT and Lesser and Greater Himalayan Sequences in Bhutan. Terra Nostra,v. 2, p. 155.

Unrug, R., 1997, Rodinia to Gondwana: the geodynamic map of Gondwana supercontinent assembly. GSA Today, v. 7 (1), pp.1-6

Valdiya, K.S., 1980. Geology of Kumaun Lesser Himalaya. Wadia Institute of Himalayan Geology.

Vance D., Harris N.B.W., 1999, Timing of prograde metamorphism in the Zanskar Himalaya. Geology, v. 27, pp. 395-398.

Van Hinsbergen, D.J., Lippert, P.C., Dupont-Nivet, G., McQuarrie, N., Doubrovine, P.V., Spakman, W. and Torsvik, T.H., 2012, Greater India Basin hypothesis and a two-stage Cenozoic collision between India and Asia.Proceedings of the National Academy of Sciences,v. 109(20), pp.7659-7664. doi.org/10.1073/pnas. 1117262109

Vigneresse, J-L. and Burg, J.-P. 2003. The paradoxial aspect of the Himalayan granite In: Singh, S., 2003,Granitiods of the Himalayan Collisional Belt. Journal of the Virtual Explorer, Electronic Edition, v. 11, ISSN 1441-8142.

Voice, P.J., Kowalewski, M., and Eriksson, K.A., 2011, Quantifying the timing and rate of crustal evolution: Global compilation of radiometrically dated detrital zircon grains. The Journal of Geology,v. 119(2), pp.109-126. doi: 10.1086/658295

Wadia, D.N., 1928, The geology of Poonch State (Kashmir) and adjacent portions of the Punjab.Memoir Geological Surveyof India,v. 51, pp.185-370.

Wadia, D.N., 1957, Geology of India.Mcmillan and Co.London,3, 536p.

Walker J.D., Martin M.W., Bowering S.A., Searle M.P., Water D.J., and Hodges K.V., 1999, Metamorphism, melting and extension: age constraints from the High Himalayan Slab of southeast Zanskar and Northwest Lahaul. The Journal of Geology, v. 107, pp. 473-495.

Wang, J., Chen, Z., Gui, X., Xu, R., and Zhang, Y., 1981, Rb-Sr isotopic studies of some intermediate-acid plutons in Southern Xizang. In: Geological and Ecological Studies of Qinghai-Xizang
Plateau, Proceedings Symposium Qinghai-Xizang, Tibet. Plateau, Peking 1980, Science Press, Beijing, v. 1, pp. 515-520.

Wang, X.C., Li, X.H., Li, W.X., and Li, Z.X., 2009, Variable involvements of mantle plumes in the genesis of midNeoproterozoic basaltic rocks in South China: a review. Gondwana Research,v. 15(3-4), pp.381-395. doi.org/10.1016/ j.gr.2008.08.003

Webb, A.A.G., Yin, A., Harrison, T.M., Célérier, J., Gehrels, G.E., Manning, C.E., and Grove, M., 2011, Cenozoic tectonic history of the Himachal Himalaya (northwestern India) and its constraints on the formation mechanism of the Himalayan orogen. Geosphere,v. 7(4), pp.1013-1061. doi.org/10. 1130/ GES00627.1

Wegener, A., 1912, Die entstehung der kontinente. Geologische Rundschau,v. 3(4), pp.276-292.

Worsley, T.R., Nance, D. and Moody, J.B., 1984, Global tectonics and eustasy for the past 2 billion years.Marine Geology,v. 58(34), pp.373-400. doi.org/10.1016/0025-3227(84)90209-3.

Yin, A., 2006, Cenozoic tectonic evolution of the Himalayan orogen as constrained by along-strike variation of structural geometry, exhumation history, and foreland sedimentation. Earth-Science Reviews,v. 76(1-2), pp.1-131. doi.org/10.1016/j.earscirev. 2005. 05.004

Yin, A., Dubey, C.S., Webb, A.A.G., Kelty, T.K., Grove, M., Gehrels, G.E., and Burgess, W.P., 2010, Geological correlation of the Himalayan orogen and Indian craton: Part 1. Structural geology, U-Pb zircon geochronology, and tectonic evolution of the Shillong Plateau and its neighboring regions in NE India. Geological Society of American Bulletin, v. 122, pp. 336-359, doi:10.1130 / B26460.1.

Zeitler, P.K., 1988,Ar diffusion in partially outgassed alkali feldspars: Insights from ${ }^{40} \mathrm{Ar}-{ }^{39} \mathrm{Ar}$ analysis-Reply.Chemical Geology: Isotope Geoscience section,v. 73(3), pp.268-269.

Zeitler, P.K., Sutter, J.F., Williams, I.S., Zartman, R., and Tahirkheli, R.A.K., 1989, Geochronology and temperature history of the Nanga Parbat-Haramosh massif, Pakistan.Geological Society of America Special Papers232, pp.1-22.

Zeitler, P.K., Chamberlain, C.P., and Smith, H.A., 1993, Synchronous anatexis, metamorphism, and rapid denudation at Nanga Parbat (Pakistan Himalaya).Geology,v. 21, pp.347-350.

Zhao, G., Cawood, P.A., Wilde, S.A., and Sun, M., 2002, Review of global 2.1-1.8 Ga orogens: implications for a pre-Rodinia supercontinent.Earth Science Reviews,v. 59(1-4), pp.125-162. doi.org/10.1016/S0012-8252(02)00073-9.

Zhao, G., Sun, M., Wilde, S.A., and Li, S., 2004, A PaleoMesoproterozoic supercontinent: assembly, growth and breakup.Earth Science Reviews,v. 67(1-2), pp.91-123. doi.org/ 10.1016/j.earscirev.2004. 02.003

Zhao, G., Wang, Y., Huang, B., Dong, Y., Li, S., Zhang, G., and Yu, S., 2018, Geological reconstructions of the East Asian blocks: From the breakup of Rodinia to the assembly of Pangaea. EarthScience Reviews. doi:10.1016/j.earscirev.2018.10.003

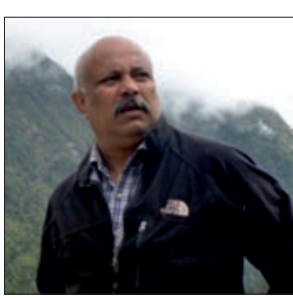

Sandeep Singh is a Professor at Department of Earth Sciences, Indian Institute of Technology Roorkee, India. His research contributions deal with the timing of various Himalayan tectonic events related to pre-Himalayan deformation, transpressional tectonics within Karakoram, timing of India-Asia collision and late stage exhumation. His work involves integration of field, petrology, geochemistry and U-Pb geochronology data set by Isotope Geochemistry and mineral chemistry using Sensitive High mass Resolution Ion MicroProbe (SHRIMP), conventional Thermal Ionization Mass Spectrometer (TIMS), ICP-MS and EPMA. 